\title{
ELITO SLIDININKŲ LENKTYNININKŲ DALYVAVIMO VARŽYBOSE PER 2007-2008 M. SEZONĄ SISTEMOS YPATUMAI
}

\author{
Algirdas Čepulėnas \\ Lietuvos kūno kultūros akademija, Kaunas, Lietuva
}

\begin{abstract}
Algirdas Čepulėnas. Socialinių mokslų (edukologijos) habilituotas daktaras, Lietuvos kūno kultūros akademijos Sportinių žaidimų katedros profesorius. Mokslinių tyrimų kryptis — sportininkų treniravimo sistemos, rengimo valdymo modeliavimas.
\end{abstract}

\section{SANTRAUKA}

Tyrimo tikslas - išnagrinèti pasaulio elito slidininku (moteru ir vyru) varžybu krūvio kiekybinius rodiklius, specifiškuma per 2007-2008 m. sezonq ir nustatyti ju varžybinés veiklos rezultatyvuma Pasaulio slidinẻjimo taurés varžybose. Išanalizuota slidininku (vyru ir moteru), Pasaulio slidinejjimo taurès varžybu galutinejje ìskaitoje užèmusiu 1-10 vieta, varžybinès veiklos rodikliai - startu skaičius, varžybu krūvio dydis (km), varžybu krūvis ilguju nuotoliu ir sprinto lenktynèse, varžybinès veiklos rezultatyvumas pagal užimtas vietas ir surinktus iskaitinius taškus Pasaulio taurès daugiaetapiu varžybu galutinèje iskaitoje. Išanalizuota slidininku, Pasaulio taurès varžybu galutinèje i̇skaitoje užèmusiu 1-30 vieta, varžybinés veiklos specializacijos ypatumai, rezultatyvumas ilguju nuotoliu ir sprinto lenktynése.

Pasaulio elito slidininku (vyru ir moteru), dalyvavimo varžybose individualiu sistemu modeliai priklauso nuo slidininku specializacijos. Išsiskiria slidininku(-iu) specializacijos grupés: slidininkai(-ès) universalai, ilguju nuotoliu slidininkai(-ès), slidininkai(-ès) sprinteriai(-ès).

Pasaulio slidinèjimo taurès varžybu pirmo dešimtuko bendrojoje isskaitoje devynios slidininkès yra universalios ir jos per sezonq 19-23 kartus dalyvavo individualiose ilguju nuotoliu lenktynèse, 2-3 kartus tradiciniu estafečiu lenktynèse. Ju varžybinès veiklos krūvis - 217-267 km. Šios grupés slidininkès po 8-12 kartu dalyvavo sprinto lenktynèse, per kurias startavo nuo 23 iki 44 kartu priklausomai nuo sportinès sèkmès.

Slidininku universalu, Pasaulio slidinèjimo taurès varžybu bendrojoje iskaitoje užèmusiu 1 -10 vieta, varžybu krūvi per sezonq sudare்: 21-24 startai individualiose ilguju nuotoliu, 2-3 startai tradiciniu estafečiu lenktynèse, per kurias jie ìveike 245-475 km. Šios grupés slidininkai 4-12 kartu dalyvavo individualiose sprinto lenktynése, kuriu metu startavo 18 - 40 kartu.

Elito slidininkès universalesnès nei elito slidininkai. Daugiadienès „, Tour de Ski“ lenktynès tapo svarbia elito slidininku varžybu sistemos dalimi.

Raktažodžiai: Pasaulio taurès varžybos, ilgieji nuotoliai, sprintas, ịskaitiniai taškai.

\section{IVADAS}

$\mathrm{P}$ er paskutinius 15 metų Pasaulio slidinèjimo taurès varžybų etapu skaičius padidejjo nuo 9 iki 19, individualių nuotolių lenktyniu — nuo 9 iki 27 (Вяльбе, 2007). Tarptautinès slidinèjimo federacijos (FIS) organizuojama slidinejjimo lenktynių varžybu programose buvo daug pokyčių: vykdomos dutlono lenktynès (pusė nuotolio slystama klasikiniais slydimo būdais, keičiamos slidès ir lazdos, antra nuotolio pusè ivveikiama čiuožiamaisiais būdais), individualios ir komandinès (po 2 dalyvius) slidinèjimo sprinto lenktynès. I 2006-2007 m. Pasaulio slidinejjimo taurès varžybu programą buvo ittrauktos ir pirmą kartą vykdomos daugiadienès slidinèjimo „Tour de Ski“ lenktynès. Jose gaunami taškai ịrašomi į bendrą Pasaulio taurès varžybų iskaitą priskaičiuojant koeficientą, didinantį šių varžybų reikšmingumą. Daugiadienių slidinejjimo lenktynių programą 
sudaro: lenktynès klasikiniais slydimo būdais ir laisvuoju (čiuožimo) stiliumi, lenktynès įveikiant tradicinius įvairaus ilgumo nuotolius, slidinejjimo sprintas, o paskutiniame daugiadienių etape vyksta persekiojimo lenktynès slystant tik į kalną. Pasaulio slidinèjimo taurès varžybos vis labiau darosi komercinès (Вяльбе, 2007).

Kai kurie elito slidininkai, pasiekdami pergaliu Pasaulio slidinejjimo taurès etapinèse varžybose, negeba pasiekti geriausių rezultatu per olimpines žiemos žaidynes arba per pasaulio slidinėjimo čempionatus (Suslovas, 1999; Čepulènas, 2006; Вяльбе, 2007).

Slidininkų dalyvavimo varžybose modeliavimas yra svarbus rengimo valdymo struktūrinis veiksnys, turintis itakos veiklos specifiškumui, sportinio meistriškumo tobulejjimui ir sportinès formos siekimui (Раменская, 2000; Ostrowski, Pfeiffer, 2007; Баталов и др., 2007; Бурдина и др., 2007).

Ankstesni slidininkų dalyvavimo varžybose modeliai jau neatitinka šio laikmečio elito slidininkų dalyvavimo varžybose sistemos. Aktuali ir elito slidininkų universalumo bei specializavimosi problema: specializacija pagal slidinejjimo stilius, tradicinius nuotolius, sprinto lenktynes, kombinuotas dutlono lenktynes. Mokslo studijose dar mažai nagrinėjama svarbi elito slidininkų rengimo sudedamoji dalis — varžybinès veiklos individualus modeliavimas, varžybų krūvio struktūra, dalyvavimo varžybose individualios sistemos.

Tyrimo tikslas - išnagrinèti pasaulio elito slidininkų (moterų ir vyrų) varžybų krūvio kiekybinius rodiklius, specifiškumą per $2007-2008 \mathrm{~m}$. sezoną ir nustatyti jų varžybinès veiklos rezultatyvumą Pasaulio slidinèjimo taurès varžybose.

Tyrimo objektas - elito slidininkų varžybu sistema, slidininkų, Pasaulio slidinejjimo taurès varžybu galutinèje iskaitoje per 2007-2008 m. sezoną užèmusių $1-10$ vietą, varžybinè veikla, slidininkų specializacija tradiciniams ir sprinto nuotoliams.

\section{TYRIMO METODIKA}

Naudoti šie tyrimo metodai: literatūros šaltinių, dokumentų analizè, lyginamoji analizè. Duomenys gauti iš Tarptautinès slidinejjimo federacijos (FIS) oficialių dokumentų: biografinès medžiagos apie elito slidininkų dalyvavimą varžybose, Pasaulio slidinèjimo taurès etapinių varžybų protokolų, „Tour de Ski““ lenktynių protokolų, Pasaulio slidinèjimo taurès varžybų galutinès įskaitos dokumen- tų (Cross country ${ }^{1,2,3,4,5}$ ). Išanalizuota slidininkių ir slidininkų, Pasaulio slidinèjimo taurès varžybų galutinejje įskaitoje užimančių $1-10$ vietą, varžybinè veikla. Išnagrinèta slidininkų (vyrų ir moteru), Pasaulio slidinejjimo taurès varžybu galutineje iskaitoje užèmusių $1-30$ vietą, varžybinès veiklos specializacijos ypatumai pagal ịskaitinius taškus tradiciniu nuotolių ir sprinto lenktynèse.

\section{REZULTATAI}

Per olimpini ketveriu metu ciklą pirmais ir trečiais metais vykdomi pasaulio slidinejimo čempionatai. Antrais ciklo metais ir olimpinių žaidyniu metais pasaulio slidinejjimo čempionatai nevyksta. Per 2007-2008 m. sezoną pasaulio čempionato nebuvo, todèl elito slidininkams pagrindinès varžybos buvo Pasaulio slidinejimo taurès etapai ir daugiadienès „Tour de Ski“ lenktynès. Pasaulio slidinėjimo taurès daugiaetapès varžybos suskirstytos i keturis laikotarpius:

I laikotarpis (2007 10 27-2007 12 16) — penki Pasaulio taurès etapai;

II laikotarpis (2007 12 28-2008 01 26) — daugiadienès „Tour de Ski“ lenktynès ir du Pasaulio taurès etapai;

III laikotarpis (2008 01 27-2008 02 27) - keturi Pasaulio taurès etapai;

IV laikotarpis (2008 03 01-2008 03 16) — keturi Pasaulio taurès etapai.

Pasibaigus kiekvieno laikotarpio varžyboms sudaromi kvalifikaciniai slidininkų sąrašai susumavus įskaitinius taškus už rezultatus ilguju nuotolių (tradicinių) ir sprinto lenktynėse. İskaitinius taškus Pasaulio slidinèjimo taurès varžybose gauna slidininkai, individualiose lenktynèse užèmę $1-30$ vietą. Už pirmą vietą skiriama 100 taškų, už kitas taškai mažèja iki vieno už 30 -ą vietą. Po kiekvieno varžybų laikotarpio slidininkai, kvalifikaciniame sąraše (reitinge) užimantys $1-30$ vietą, iš Tarptautinès slidinejjimo federacijos gauna finansavimą dalyvauti kito laikotarpio varžybose. Tokia sistema skatina slidininkus dažnai dalyvauti Pasaulio taurès varžybų etapinėse lenktynèse ir siekti užimti aukštas vietas kvalifikaciniame sąraše. Dèl šios priežasties didelè dalis elito slidininkų dalyvauja ilgujų nuotolių ir sprinto, daugiadienėse „Tour de Ski“" lenktynèse.

Pasaulio slidinèjimo taurès pirmo bendrosios i̊skaitos dešimtuko slidininkès per sezoną 19-23 kartus dalyvavo individualiose ilgujų nuotoliu ir dar 2-3 kartus - tradicinių estafečių lenktynèse (1 lent.). Visos pirmo dešimtuko slidininkès nuo 3 
1 lentelè. Slidininkių, $2007-2008$ m. Pasaulio slidinėjimo taurès varžybų bendrojoje įskaitoje užèmusių $1-10$ vietą, varžybų krūvio rodikliai per $2007-2008 \mathrm{~m}$. sezoną

\begin{tabular}{|c|c|c|c|c|c|c|c|c|}
\hline \multirow[b]{2}{*}{$\begin{array}{c}\text { Užimta } \\
\text { vieta }\end{array}$} & \multirow[b]{2}{*}{ Pavarde், vardas } & \multirow[b]{2}{*}{ Šalis } & \multicolumn{3}{|c|}{ Tradiciniai nuotoliai } & \multicolumn{3}{|c|}{ Sprintas } \\
\hline & & & $\begin{array}{l}\text { Startų skaičius } \\
\text { individualiose } \\
\text { lenktynėse }\end{array}$ & $\begin{array}{c}\text { Estafetė } 4 \times 5 \\
\text { km, startų } \\
\text { skaičius }\end{array}$ & $\begin{array}{c}\text { Bendras } \\
\text { varžybų } \\
\text { krūvis, km }\end{array}$ & $\begin{array}{c}\text { Individualių } \\
\text { lenktynių } \\
\text { skaičius }\end{array}$ & $\begin{array}{c}\text { Startų } \\
\text { skaičius }\end{array}$ & $\begin{array}{c}\text { Sprinto } \\
\text { estafetès } \\
\text { lenktynių } \\
\text { skaičius }\end{array}$ \\
\hline 1 & Kuitunen Virpi & Suomija & 20 & 3 & 242 & 10 & 37 & 1 \\
\hline 2 & Jacobsen Astrid & Norvegija & $21+1$ nebaigè & 2 & 227 & 12 & 44 & 2 \\
\hline 3 & Kowalczyk Justyna & Lenkija & $22+1$ nebaigè & - & 217 & 9 & 31 & - \\
\hline 4 & Kalla Charlotte & Švedija & 21 & 3 & 267 & 8 & 23 & 2 \\
\hline 5 & Majdic Petra & Slovėnija & 21 & 1 & 217 & 10 & 37 & 1 \\
\hline 6 & Shevcenko Valentina & Ukraina & 23 & - & 247 & 3 & 3 & - \\
\hline 7 & Follis Arianna & Italija & 19 & 2 & 232 & 10 & 30 & 1 \\
\hline 8 & Nystad Claudia & Vokietija & 19 & 3 & 232 & 12 & 28 & 2 \\
\hline 9 & Saarinen Aino-Keisa & Suomija & 20 & 3 & 242 & 11 & 28 & 2 \\
\hline 10 & Sachenbacher-Stehle Evi & Vokietija & 22 & 3 & 262 & 11 & 28 & 2 \\
\hline
\end{tabular}

2 lentelè. Slidininkių, pagal ilgųjų nuotolių lenktynių rezultatus Pasaulio slidinėjimo taurès varžybų galutinėje įskaitoje užèmusių 1-10 vietą, varžybinès veiklos rezultatyvumas pagal kitas taurès varžybų programos dalis

\begin{tabular}{|c|c|c|c|c|c|}
\hline \multirow{2}{*}{$\begin{array}{c}\text { Užimta } \\
\text { vieta ilgụjų } \\
\text { nuotolių } \\
\text { lenktynių } \\
\text { iskaitoje }\end{array}$} & \multirow[b]{2}{*}{ Slidininkès pavardè, vardas } & \multirow[b]{2}{*}{ Šalis } & \multicolumn{3}{|c|}{$\begin{array}{c}\text { Užimtos vietos pasaulio slidinėjimo taurès varžybų ịskaitoje pagal } \\
\text { programos dalis }\end{array}$} \\
\hline & & & $\begin{array}{l}\text { Galutinė įskaita (visos } \\
\text { programos dalys) }\end{array}$ & Sprinto lenktynès & $\begin{array}{l}\text { Daugiadienės } \\
\text { „Tour de Ski“6 } \\
\text { lenktynės }\end{array}$ \\
\hline 1 & Kuitunen Virpi & Suomija & 1 & 3 & 2 \\
\hline 2 & Shevcenko Valentina & Ukraina & 6 & 38 & 4 \\
\hline 3 & Kowalczyk Justyna & Lenkija & 3 & 8 & 7 \\
\hline 4 & Jacobsen Astrid & Norvegija & 2 & 2 & 16 \\
\hline 5 & Nystad Claudia & Vokietija & 8 & 13 & 6 \\
\hline 6 & Bjoergen Marit & Norvegija & 11 & 16 & nebaigè \\
\hline 7 & Kalla Charlotte & Švedija & 4 & 18 & 1 \\
\hline 8 & Saarinen Aino-Keisa & Suomija & 9 & 6 & 17 \\
\hline 9 & Follis Arianna & Italija & 7 & 9 & 3 \\
\hline 10 & Sachenbacher-Stehle Evi & Vokietija & 10 & 11 & 8 \\
\hline
\end{tabular}

iki 12 kartu dalyvavo individualiose sprinto lenktynèse. Slidininkių, dalyvaujančių tose pačiose sprinto lenktynėse, startu skaičius skiriasi, o ji lemia gebėjimai ir sportinè sėkmè.

Per vienerias sprinto lenktynes slidininkas gali startuoti tik vieną kartą, jei po kvalifikaciniu lenktynių nepatenka i kitą etapą. Keturis kartus gali startuoti, jei dalyvauja A arba B finalo lenktynèse.

Pirmo bendrosios iskaitos dešimtuko slidininkès per sezoną $1-2$ kartus dalyvavo komandinèse (estafetė $2 \times 3 \times 0,8-1,3 \mathrm{~km}$ ) sprinto lenktynèse. Slidininkès, pagal ilgujų nuotolių rezultatus bendrojoje iskaitoje užimančios $1-10$ vietă, gauna taškų už sprinto lenktynes, o 9 šios grupès slidininkès patenka i pajègiausiujų sprinterių dvidešimtuką (2 lent.).

90\% slidininkių, daugiaetapių Pasaulio slidinèjimo taurès varžybų bendrojoje iskaitoje užimančiu $1-30$ vietą (3 lent.), turi ískaitiniu tašku už ilguju nuotoliu lenktynes, o 28 -ios $(93,33 \%)$ šios grupès slidininkès - už sprinto lenktynes. 26-ios
$(86,66 \%)$ šios grupès slidininkès patenka i pirmą ilguju nuotoliu slidininkių trisdešimtuką ir 20 $(66,66 \%)$ - i pirmą sprinterių trisdešimtuką.

Slidininkès, sprinto lenktynèse užimančios $1-30$ vietą, mažiau universalios - iš jų tik 20 $(66,66 \%)$ turi įskaitinių taškų už ilguju nuotoliu rezultatus.

Elito slidininkai per sezoną 15-21 kartų dalyvavo individualiose ilgujų nuotolių ir 2-3 kartus tradicinių estafečiu lenktynèse, o jų krūvis šiose varžybose siekė $245-475 \mathrm{~km}$ (4 lent.).

Visi bendrosios įskaitos pirmo dešimtuko slidininkai dar 2-6 kartus dalyvavo individualiose sprinto lenktynèse. Per sprinto lenktynes slidininkų individualių startų skaičius skirtingas - nuo 3 iki 40. Startu skaičius sprinto lenktynèse leidžia spręsti apie slidininkų specializaciją šiai rungčiai.

Slidininkai, pagal ilgujų nuotolių rezultatus Pasaulio slidinèjimo taurès varžybų bendrojoje iskaitoje užèmę $1-10$ vietą ( 5 lent.), turi tašku ir už rezultatus sprinto lenktynėse. Trys slidininkai 
3 lentelè. Slidininkų(-ių), $2007-2008 \mathrm{~m}$. Pasaulio slidinėjimo taurès varžybų galutinèje įskaitoje užèmusių $1-30$ vietą, varžybinès veiklos ypatumai

\begin{tabular}{|c|c|c|c|}
\hline $\begin{array}{l}\text { Eil. } \\
\text { Nr. }\end{array}$ & Slidininkų grupės ir jų varžybinės veiklos požymiai & $\begin{array}{l}\text { Slidininkų } \\
\text { skaičius }\end{array}$ & Procentai \\
\hline & Slidininkès & & \\
\hline \multirow{6}{*}{1} & \multicolumn{3}{|l|}{$\begin{array}{l}\text { Slidininkès, pagal ilgujų nuotolių, sprinto ir daugiadienių „Tour de Ski“" } \\
\text { lenktynių rezultatus bendrojoje įskaitoje užėmusios } 1-30 \text { vietą }\end{array}$} \\
\hline & 1. Turi taškų už ilgujų nuotolių lenktynes & 27 & 90 \\
\hline & 2. Turi taškų už sprinto lenktynes & 28 & 93,33 \\
\hline & 3. Patenka į trisdešimtuką pagal ilgujų nuotolių lenktynių rezultatus & 26 & 86,66 \\
\hline & 4. Patenka i trisdešimtuką pagal sprinto lenktynių rezultatus & 20 & 66,66 \\
\hline & 5. Patenka į daugiadienių „Tour de Ski“ lenktynių trisdešimtuką & 24 & 80 \\
\hline \multirow{4}{*}{2} & \multicolumn{3}{|l|}{ Slidininkès, pagal ilgujų nuotolių lenktynių rezultatus užèmusios $1-30$ vietą } \\
\hline & 1. Turi taškų už rezultatus sprinto lenktynèse & 27 & 90 \\
\hline & 2.Patenka į sprinterių trisdešimtuką & 16 & 53,33 \\
\hline & 3. Patenka į daugiadienių „Tour de Ski“ lenktynių trisdešimtuką & 24 & 80 \\
\hline \multirow{4}{*}{3} & \multicolumn{3}{|l|}{ Slidininkès, pagal sprinto lenktynių rezultatus užèmusios $1-30$ vietą } \\
\hline & 1. Turi taškų už rezultatus ilgujų nuotolių lenktynèse & 20 & 66,66 \\
\hline & 2. Patenka į trisdešimtuką pagal ilgujų nuotolių lenktynių rezultatus & 17 & 55,66 \\
\hline & 3. Patenka į daugiadieniu „Tour de Ski“ lenktynių trisdešimtuką & 17 & 56,66 \\
\hline & \multicolumn{3}{|l|}{ Slidininkai } \\
\hline \multirow{6}{*}{1} & \multicolumn{3}{|l|}{$\begin{array}{l}\text { Slidininkai, pagal ilgujų nuotolių, sprinto ir daugiadienių „Tour de Ski“ } \\
\text { lenktynių rezultatus bendrojoje įskaitoje užėmę } 1-30 \text { vietą }\end{array}$} \\
\hline & 1. Turi taškų už ilgujų nuotolių lenktynes & 24 & 80 \\
\hline & 2. Turi tašku už sprinto lenktynes & 30 & 100 \\
\hline & 3. Patenka į trisdešimtuką pagal ilgujų nuotolių lenktynių rezultatus & 21 & 70 \\
\hline & 4. Patenka i trisdešimtuką pagal sprinto lenktynių rezultatus & 16 & 53,33 \\
\hline & 5. Patenka į daugiadienių „Tour de Ski“ lenktynių trisdešimtuką & 22 & 73,33 \\
\hline \multirow{4}{*}{2} & \multicolumn{3}{|l|}{ Slidininkai, pagal ilgujų nuotolių lenktynių rezultatus užèmę $1-30$ vietą } \\
\hline & 1. Turi taškų už rezultatus sprinto lenktynèse & 25 & 83,33 \\
\hline & 2. Patenka į sprinterių trisdešimtuką & 8 & 26,66 \\
\hline & 3. Patenka į daugiadienių „Tour de Ski“ lenktynių trisdešimtuką & 21 & 70 \\
\hline \multirow{4}{*}{3} & \multicolumn{3}{|l|}{ Slidininkai, pagal sprinto lenktynių rezultatus užèmę $1-30$ vietą } \\
\hline & 1. Turi taškų už rezultatus ilgujų nuotolių lenktynèse & 13 & 43,33 \\
\hline & 2. Patenka į trisdešimtuką pagal ilgujų nuotolių lenktynių rezultatus & 8 & 26,66 \\
\hline & 3. Patenka į daugiadienių „Tour de Ski“ lenktynių trisdešimtuką & 8 & 26,66 \\
\hline
\end{tabular}

4 lentelè. Slidininkų, 2007—2008 m. Pasaulio slidinėjimo taurès varžybų bendrojoje ịskaitoje užèmusių 1—10 vietą, varžybų krūvio rodikliai per 2007-2008 m. sezoną

\begin{tabular}{|c|c|c|c|c|c|c|c|c|}
\hline \multirow[b]{2}{*}{$\begin{array}{c}\text { Užimta } \\
\text { vieta }\end{array}$} & \multirow[b]{2}{*}{$\begin{array}{c}\text { Slidininko } \\
\text { pavardė, vardas }\end{array}$} & \multirow[b]{2}{*}{ Šalis } & \multicolumn{3}{|c|}{ Tradiciniai nuotoliai } & \multicolumn{3}{|c|}{ Sprintas } \\
\hline & & & $\begin{array}{c}\text { Startų skaičius } \\
\text { individualiose } \\
\text { lenktynėse }\end{array}$ & $\begin{array}{c}\text { Estafetė } \\
4 \times 10 \\
\text { km, startų } \\
\text { skaičius }\end{array}$ & $\begin{array}{c}\text { Bendras } \\
\text { varžybų } \\
\text { krūvis, km }\end{array}$ & $\begin{array}{c}\text { Individualių } \\
\text { lenktynių } \\
\text { skaičius }\end{array}$ & $\begin{array}{c}\text { Startụ } \\
\text { skaičius }\end{array}$ & $\begin{array}{c}\text { Sprinto } \\
\text { estafetès } \\
\text { lenktynių } \\
\text { skaičius }\end{array}$ \\
\hline 1 & Bauer Lukas & Čekija & 18 & 3 & 345 & 4 & 7 & 1 \\
\hline 2 & Sommerfeld Rene & Vokietija & 20 & 3 & 415 & 6 & 10 & - \\
\hline 3 & Piller Cottrer Pietro & Italija & 21 & 2 & 405 & 4 & 4 & - \\
\hline 4 & Gjerdalen Tord Aste & Norvegija & $21+1$ nebaigè & 3 & 375 & 4 & 12 & - \\
\hline 5 & Di Centa Giorgia & Italija & 21 & 3 & 415 & 3 & 9 & - \\
\hline 6 & Hetland Tor Arne & Norvegija & $18+1$ nebaigè & 2 & 322 & 12 & 40 & 1 \\
\hline 7 & Soedergren Anders & Švedija & 21 & 3 & 475 & 3 & 4 & - \\
\hline 8 & Teichmann Axel & Vokietija & $14+1$ nebaigè & 3 & 245 & 6 & 11 & - \\
\hline 9 & Svartedal Jens Arne & Norvegija & 19 & 3 & 310 & 9 & 18 & 1 \\
\hline 10 & Chesshi Valerio & Italija & 20 & 2 & 355 & 2 & 3 & - \\
\hline
\end{tabular}

patenka i pirmą sprinterių trisdešimtuką, aštuoni - i pirmą Pasaulio slidinèjimo taurès varžybu bendrosios iskaitos dešimtuką.

Penki šios grupès slidininkai dalyvavo „Tour de Ski“ lenktynėse, bet jas baigè tik trys.
Slidininkai, Pasaulio slidinèjimo taurès varžybų bendrojoje iskaitoje užèmę $1-30$ vietă, yra universalai - iš jų 24 slidininkai ( $80 \%$ ) turi taškų už rezultatus ilgujų nuotolių lenktynèse ir visi $30(100 \%)$ už rezultatus sprinto lenktynėse (3 lent.). 
5 lentelè. Slidininkų, pagal ilgụjų nuotolių rezultatus $2007-2008$ m. Pasaulio slidinẻjimo taurès varžybų galutinèje įskaitoje užèmusių 1 - 10 vietą, varžybinès veiklos rezultatyvumas pagal kitas taurẻs varžybų programos dalis

\begin{tabular}{|c|c|c|c|c|c|}
\hline \multirow{2}{*}{$\begin{array}{c}\text { Užimta vieta } \\
\text { ilgųjų nuotolių } \\
\text { lenktynių } \\
\text { įskaitoje }\end{array}$} & \multirow{2}{*}{ Slidininko pavardė, vardas } & \multirow{2}{*}{ Šalis } & \multicolumn{3}{|c|}{$\begin{array}{c}\text { Užimtos vietos Pasaulio slidinèjimo taurės varžybų iskaitoje pagal } \\
\text { programos dalis }\end{array}$} \\
\hline & & & $\begin{array}{c}\text { Galutinè iskaita } \\
\text { (visos programos dalys) }\end{array}$ & Sprinto lenktynès & $\begin{array}{c}\text { Daugiadienès } \\
\text { „Tour de Ski“ lenktynės }\end{array}$ \\
\hline 1 & Bauer Lukas & Čekija & 1 & 35 & 1 \\
\hline 2 & Piller Cottrer Pietro & Italija & 3 & 19 & 7 \\
\hline 3 & Sommerfeld Rene & Vokietija & 2 & 81 & 2 \\
\hline 4 & Vittoz Vincent & Prancūzija & 11 & 53 & - \\
\hline 5 & Soedergren Anders & Švedija & 7 & 42 & 16 \\
\hline 6 & Checchi Valerio & Italija & 10 & 68 & 15 \\
\hline 7 & Di centa Giorgio & Italija & 5 & 38 & 3 \\
\hline 8 & Teichmann Axel & Vokietija & 8 & 29 & 13 \\
\hline 9 & Gjerdalen Tord Asle & Norvegija & 4 & 18 & 4 \\
\hline 10 & Nousiainen Ville & Suomija & 17 & 55 & 19 \\
\hline
\end{tabular}

Iš slidininkų, pagal ilgujų nuotolių varžybų rezultatus bendrojoje iskaitoje užèmusių $1-30$ vietą, 25 slidininkai $(83,3 \%)$ turi taškų už rezultatus sprinto lenktynèse, o i pajègiausiujų sprinterių trisdešimtuką patenka aštuoni $(26,66 \%)$. Iš pajègiausiujų sprinto slidininkų trisdešimtuko tik 13 slidininkų $(43,33 \%)$ turi taškų už rezultatus ilguju nuotolių lenktynèse (3 lent.).

\section{REZULTATUQ APTARIMAS}

Šiuolaikinėse slidinėjimo lenktynėse sportinès formos igijimo valdymas labai susijęs su įvairaus lygio varžybų ir startu skaičiaus (pagal ịveikimo stilių ir nuotolio ilgi) planavimu (Баталов и др., 2007; Бурдина и др., 2007; Вяльбе, 2007; С̌ерulènas, 2006, 2008, 2009). FIS varžybų sistema skatina slidininkus, siekiančius užimti aukštas vietas galutinèje Pasaulio slidinėjimo taurès varžybu įskaitoje, dalyvauti varžybose klasikiniu ir laisvuoju stiliumi. Slidininkai, kurie specializuojasi lenktynėms tik vienu stiliumi, mažiau kartu startuoja Pasaulio slidinejjimo taurès varžybose. Tokio tipo slidininkai nepajègūs siekti gerų rezultatų dutlono lenktynèse ir jose nedalyvauja.

Dutlono (15 km moterims ir $30 \mathrm{~km}$ vyrams), $30 \mathrm{~km}$ moterims ir $50 \mathrm{~km}$ vyrams lenktynèse startuojant bendruoju startu, lenktynių lyderių grupé (dažnai iki 10 ir daugiau slidininkų) iki paskutinio nuotolio kilometro slysta kartu ir vietu pasiskirstymą lemia finišo sprinterinis spurtas. Finišuojant ilgujų nuotolių slidininkams būtina pasiekti didelị sprinterini slydimo greiti. Slidininkai, norėdami lavinti slydimo greiti ir greičio ištvermę, dalyvauja ir slidinejjimo sprinto lenktynèse.

Pagal ilgųu nuotoliu rezultatus pajègiausios 2007-2008 m. pasaulio slidininkès V. Kuitunen (1 vieta), J. Kowalczyk (3), A. Jo- cobsen (4), A. K. Saarinen (8), A. Follis (9) yra universalios slidininkès. Jos užèmè aukštas vietas sprinteriu klasifikacijoje ir pagal sprinto rezultatus - atitinkamai 3, 8, 2, 6, 9 vietą. P. Majdic, Pasaulio taurès sprinto varžybu klasifikacijoje užèmusi pirmą vietą, yra universali slidininkè - ji bendrojoje iskaitoje pagal visas programos rungtis užèmė penktą vieta. Ši slidininkè 21 kartą dalyvavo individualiose ilguju nuotoliu ir 37 kartus sprinto lenktynèse. Per $2007-2008 \mathrm{~m}$. sezoną Pasaulio slidinejjimo taurès sprinto lenktynèse pajègiausiuju slidininkiu ( $1-30$ vieta) vidutinis varžybinis greitis klasikiniais slydimo būdais siekè $7,07 \pm 0,86 \mathrm{~m} / \mathrm{s}$, čiuožiamaisiais $-7,93 \pm$ $0,79 \mathrm{~m} / \mathrm{s}$ (Stöggl et al., 2009). Slydimo greičiai $15 \mathrm{~km}$ dutlono lenktynèse $-5,92 \mathrm{~m} / \mathrm{s}, 30 \mathrm{~km}$ lenktynèse čiuožiamaisiais būdais $-6,21 \mathrm{~m} / \mathrm{s}$, slystant klasikiniu stiliumi $-5,73 \mathrm{~m} / \mathrm{s}$ (Stöggl et al., 2009).

Pasaulio elito slidininkes pagal jų varžybinès veiklos specifiškumą ir pasiektus rezultatus lenktynèse galima sąlygiškai skirti $\mathfrak{i}$ tris grupes:

- slidininkès universalès, kurios pasiekia puikius rezultatus ilgujų nuotolių ir sprinto lenktynèse;

- ilguju nuotolių slidininkès, pasiekiančios geriausius rezultatus ilguju $(10-30 \mathrm{~km})$ nuotoliu lenktynèse, retai dalyvaujančios arba visai nedalyvaujančios slidinèjimo sprinto lenktynèse;

- slidininkès sprinterès, užimančios aukštas vietas sprinto lenktynėse, mažai dalyvaujančios ilgujų nuotolių lenktynèse, neturinčios įskaitinių taškų už rezultatus ilgujų nuotolių lenktynėse.

Kiekvienos grupès slidininkių dalyvavimo varžybose modelis skirtingas. Slidininkès universalès per sezoną 19-23 kartus dalyvavo individualiose ilguju nuotolių, 2-3 kartus tradicinių estafečiu lenktynėse, ir tokių varžybų individualus krūvis siekè $217-267 \mathrm{~km}$. Šios grupès slidininkès po 
8-12 kartų dalyvavo sprinto lenktynèse, per kurias startavo nuo 23 iki 44 kartu priklausomai nuo sportinès sėkmès. Slidininkès universalès sprinto lenktynèse pajėgios lygiaverčiai konkuruoti su sprinteremis, o ilguju nuotolių lenktynèse jos net pajègesnès už slidininkes, kurios daugiau specializuojasi ilgujų nuotolių lenktynèms ir retai dalyvauja sprinto lenktynèse. Slidininkès universalès užèmè septynias vietas šio sezono pajègiausiuju sprinterių dešimtuke.

Slidininkès sprinterès nedalyvauja daugiadienèse „Tour de Ski“" lenktynėse, o ilgujų nuotolių lenktynèse dažniau dalyvauja sezono pradžioje ir pabaigoje.

2007 m. pasaulio slidinejjimo čempionate Sappore aštuonios slidininkès laimèjo visus 12 medaliu individualiose lenktynèse (ilgujų nuotolių ir sprinto) ir visos jos iki pasaulio čempionato pradžios nuo 10 iki 12 kartų dalyvavo ilgujų nuotolių lenktynėse, nuo vieno iki šešių kartų sprinto lenktynèse, per kurias startavo nuo vieno iki 24 kartu (Čepulènas, 2009). Medalių laimètojos buvo slidininkès universalès. Aukso medalių laimètojos K. Neumannova (10 km laisvuoju stiliumi) ir V. Kuitunen $(30 \mathrm{~km}$ klasikiniu stiliumi) iki čempionato pradžios atitinkamai 13 ir 24 kartus startavo sprinto lenktynėse. Šešios slidininkès, laimèjusios medalius individualiose šio čempionato lenktynèse, buvo dalyvavusios ir daugiadienèse „Tour de Ski“ lenktynèse sezono pradžioje (Čepulènas, 2009).

Slidininkai, 2007-2008 m. Pasaulio taurès varžybų bendrojoje įskaitoje užèmę $1-10$ vieta, yra universalai - visi turejo įskaitinių taškų už ilgujų nuotolių, sprinto ir daugiadieniu „Tour de Ski“ lenktyniu rezultatus (3 pav.). Šioje universalių slidininku grupejje galima išskirti (3 pav.):

- slidininkus stajerius universalus (užèmusius 1, 2, 3, 4, 5, 7, 10 vieta);

- slidininkus sprinterius universalus (užėmusius 6, 9 vieta).

Atsižvelgiant ị slidininkų dalyvavimo varžybose specifiką ir pasiektus rezultatus dar galima išskirti:

- ilgujų nuotoliu slidininkus ir retai dalyvaujančius arba visai nedalyvaujančius slidinejjimo sprinto lenktynėse, neturinčius įskaitinių tašku už sprinto rezultatus;

- slidininkus sprinterius, dalyvaujančius tik sprinto lenktynèse.

2007-2008 m. sezono pajègiausiujų Pasaulio slidinejjimo taurès sprinterių dešimtuke buvo tik du slidininkai, turintys taškų už ilguju nuotolių rezultatus ir šioje grupèje užimantys 16 ir 21 vietą.
Universaliujų slidininkų stajerių varžybų krūvis per sezoną - 21-24 startai ilgujų nuotoliu lenktynėse ir nuo 4 iki 12 startu sprinto lenktynèse. Šios grupès slidininkų varžybų krūvis ilgujų nuotolių lenktynėse siekia nuo $245 \mathrm{iki} 415 \mathrm{~km}$ per sezoną (4 lent.).

Remiantis F. Suslovo (Суслов, 1995) duomenimis, slidininkų varžybinès veiklos krūvis $(\mathrm{km})$ sudaro $7-10 \%$ viso treniruotès krūvio. G. Neumann ir kt. (2000) pažymi, kad slidininkų varžybų krūvis $(\mathrm{km})$ turi siekti $5 \%$ ciklinio darbo krūvio per sezoną. Didẻjant slidininkų amžiui, elito slidininkų startu skaičius per sezoną mažèja ir jie daugiau rengiasi toms varžyboms, kuriose tikisi pasiekti geriausių rezultatų (Вяльбе, 2007).

Per 2007-2008 m. sezoną Pasaulio slidinèjimo taurès sprinto lenktynėse pajėgiausiuju slidininkų (užėmusių $1-30$ vietą) vidutinis varžybinis greitis klasikiniais slydimo būdais $-7,63 \pm 0,91 \mathrm{~m} / \mathrm{s}$, čiuožiamaisiais $-8,84 \pm 0,76 \mathrm{~m} / \mathrm{s}$ (Stöggl et al., 2009).

Šiuolaikiniai slidininkų visuotiniai slydimo greičiai yra tokie: $15 \mathrm{~km}$ lenktynėse klasikiniu stiliumi $-7,06 \mathrm{~m} / \mathrm{s}$, laisvuoju stiliumi $-6,51 \mathrm{~m} / \mathrm{s}$, $30 \mathrm{~km}$ lenktynèse klasikiniu stiliumi $-6,27 \mathrm{~m} / \mathrm{s}$, laisvuoju stiliumi $-6,82 \mathrm{~m} / \mathrm{s}, 30 \mathrm{~km}$ dutlono lenktynèse - 6,48 m / s (Stöggl et al., 2009).

Slidininkai sprinteriai (vyrai) sprinto lenktynèse užima pirmaujančias pozicijas. Slidininkai universalai ir slidininkai stajeriai dalyvauja sprinto lenktynèse ugdydami maksimaluji slydimo greiti. Jie geba gauti įskaitinių tašku, bet pirmaujančiu pozicijų neužima. Elito slidininkès, palyginti su slidininkais vyrais, yra universalesnès.

\section{IŠVADOS}

1. Pasaulio elito slidininkų (vyru ir moterų) dalyvavimo varžybose individuali sistema priklauso nuo specializacijos. Išskirtinos tokios slidininkų(-ių) specializacijos grupès:

- slidininkai universalai, kurie gali būti ir stajeriai, ir sprinteriai;

- ilgujų nuotolių slidininkai;

- slidininkai sprinteriai.

2. Pasaulio elito slidininkų(-ių) didžiausią varžybų krūvio dalị sudaro Pasaulio slidinejjimo taurès varžybos. Daugiadienès „Tour de Ski“ lenktynès tapo svarbia elito slidininkų varžybų sistemos dalimi. Šiose lenktynèse dalyvauja slidininkai universalai, Pasaulio taurès varžybų bendrojoje įskaitoje siekiantys aukštų vietụ. 


\title{
LITERATŪRA
}

Cross-country ${ }^{1}$. Biography. Athlete information. Prieiga internetu: http://ww.fis-ski.com

Cross-country ${ }^{2}$. FIS World Cup Calendar 2007-2008. Prieiga internetu: http://www.fis-ski.com

Cross-country ${ }^{3}$. Results. World Cup 2007-2008. Prieiga internetu: http://www.fis-ski.com

Cross-country ${ }^{4}$. Tour de Ski 2007-2008. Results. Prieiga internetu: http://www.fis-ski.com

Cross-country ${ }^{5}$. World Cup Standings. Prieiga internetu: http://www.fis-ski.com

Čepulènas, A. (2006). Elito slidininkų varžybinès veiklos charakteristika. Ugdymas. Küno kultūra. Sportas, 4 (63), $21-28$.

Čepulènas, A. (2009). Individual modeling of the competition activities for elite female ski races during the 2006-2007 season. Science and Skiing IV. Edited by E. Müller, S. Lindinger, T. Stöggl. Oxford: Meyer \& Meyer Sport (UK) Ltd. P. 585-595.

Čepulènas, A. (2008). The competition activity of elite cross-country skiers during the 2006-2007 season. $A b$ stract book. The First International Low Lands Congress on Science and Skiing. Brussels, October $11^{\text {th }}$ (pp. 59-62). The Brussels Ski team and the Vrije Universiteit Brussel. Neumann, G., Pfützner, A., Berbalk, A. (2000). Successful Endurance Training. Oxford: Meyer \& Meyer Sport (UK) Ltd. P. $148-149$.

Ostrowski, Ch., Pfeifer, M. (2007). Ein Modellansatz Zur Aufklärung der Leistungsstruktur im Skilanglauf. Leistungssport, 2 (37), 37-39.

Stöggl, T., Stöggl, J., Müller, E. (2009). Competition analysis of the last decade (1996-2008) in cross-country skiing. Science and Skiing IV. Edited by E. Müller, S. Lindinger, T. Stöggl. Oxford: Meyer \& Meyer Sport (UK) Ltd. P. $657-677$.

Suslovas, F. (1999). Individualių sporto šakų varžybų sistema šiuolaikiniame sporto raidos etape. Treneris, 2 , $22-31$.

Баталов, А. Г., Бурдина, М. Е., Грушин, А. А., Бояринов, А. А. (2007). Оптимизация построения соревновательного мезоцикла лыжников-гонщиков в период подготовки к зимним олимпийским играм: сборник научных трудов, посвящённый 70-летию образования кафедры теории и методики лыжного спорта РГУФК. Москва: РГУФК. С. 18-23.

Бурдина, М. Е., Баталов, А. Г., Грушин, А. А., Бояринов, А. А. (2007). Моделирование индивидуальных систем соревнований льжниц-гонщии высокого класса в период подготовки к олимпийским играм и чемпионатам мира: сборник научных трудов, посвящённый 70-летию образования кафедры теории и методики лыжного спорта РГУФК. Москва: РГУФК. С. 32-36.

Вяльбе, Е. В. (2007). Система соревнований и структура этапа непосредственной подготовки к главному старту высококвалифицированных лыжников-гонщииков: автореферат диссертации на соискание учёной степени кандидата педагогических наук. Москва.

Раменская, Т. И. (2000). Биоэнергетическое моделирование соревновательной деятельности сильнейших лыжников-гонщиков на XVIII зимних олимпийских играх (Нагано, 1998). Теория и практика физической культуры, 2, 6-12.

Суслов, Ф. П. (1995). К теории индивидуальной системы соревнований. Теория и практика физической культуры, 8, 37-39.

\section{PECULIARITIES OF THE SYSTEM OF ELITE SKI RACERS' PARTICIPATION IN COMPETITIONS IN THE SEASON OF 2007-2008}

\author{
Algirdas Čepulènas \\ Lithuanian Academy of Physical Education, Kaunas, Lithuania
}

\begin{abstract}
The aim of the research was to analyze the quantitative indices and the specificity of the contest loads of the world elite skiers (males and females) and to establish the contest outcomes in the season of 2007-2008. We analyzed the contest indices of male and female skiers who took the $1^{\text {st }}-10^{\text {th }}$ places in the final credit of skiing World Cup competitions - the number of starts, the contest load $(\mathrm{km})$, the contest load in long distance and sprint racing, the contest outcomes according to the places taken and the credit points in the final credit of the World Cup multi-stage race. We also analyzed the specialization peculiarities of the competitive activities and the long distance and sprint outcomes of male and female skiers who took the $1^{\text {st }}-30^{\text {th }}$ places in the final credit of the World Cup race.
\end{abstract}


We established that the models of individual systems of the world elite male and female skiers' participation in the competitions depended on the type of skiers' specialization. The groups of male and female skiers' specialization are as follows:

- Universal male and female skiers who take high places in the final total credit of the skiing World Cup races (according to the long distance and sprint outcomes). This group includes universal skiers - stayers and sprint racers;

- Long distance skiers;

- Ski sprinters.

In the total credit of the first ten of the World Cup ski races nine female skiers were universal, and they participated 19-23 times in the individual long distance races and 2-3 times in traditional relay races in a season. Their contest load was $217-267 \mathrm{~km}$. The skiers of this group participated in sprint races $8-12$ times, where they started 23-24 times depending on their athletic success.

The contest load of universal male skiers who took the $1^{\text {st }}-10^{\text {th }}$ places in the final total credit of the World Cup skiing races in one season included $21-24$ starts in individual long distance races, $2-3$ starts in traditional relay races, and they covered $245-475 \mathrm{~km}$. The skiers of this group participated in individual sprint races $4-12$ times, where they started $18-40$ times. The majority of skiers who took the $1^{\text {st }}-30^{\text {th }}$ places in the final total credit of the World Cup skiing races had credit points for their results in long distance and sprint races.

Elite female skiers were more universal than elite male skiers. A multi-day Tour de Ski tournament became an important part of elite skiers' contest system.

Keywords: World Cup contest, long distance, sprint, credit points.

Gauta 2009 m. vasario 9 d.

Received on February 9, 2009

Priimta 2009 m. gegužès 26 d.

Accepted on May 26, 2009
Algirdas Čepulènas

Lietuvos kūno kultūros akademija

(Lithuanian Academy of Physical Education)

Sporto g. 6, LT-44221 Kaunas

Lietuva (Lithuania)

Tel +37068584246

E-mail a.cepulenas@1kka.1t 